\title{
TRANSPORTATION OF JUVENILE TAMBAQUI (Colossoma macropomum) IN A CLOSED SYSTEM
}

\author{
GOMES, L. C. ${ }^{1}$, ARAUJO-LIMA, C. A. R. M. ${ }^{2 *}$, \\ CHIPPARI-GOMES, A. R. ${ }^{2}$ and ROUBACH, R. ${ }^{2}$ \\ ${ }^{1}$ Embrapa Amazônia Ocidental, CEP 69011-970, C. P. 319, Manaus, AM, Brazil \\ ${ }^{2}$ Instituto Nacional de Pesquisas da Amazônia, CEP 69011-970, C. P. 478, Manaus, AM, Brazil \\ *In memorian \\ Correspondence to: Levy de Carvalho Gomes, Embrapa Amazônia Ocidental, CEP 69011-970, \\ C. P. 319, Manaus, AM, Brazil, e-mail: levy@cpaa.embrapa.br \\ Received May 6, 2004 - Accepted September 28, 2004 - Distributed May 31, 2006
}

(With 6 figures)

\begin{abstract}
The objective of this study was to investigate the effect of density, duration and the use of additives to the water during the transportation of juvenile tambaqui (Colossoma macropomum) and use of this data to establish a safe transportation protocol for the species. The tested products and dosages were: salt (1000, 2000 and $3000 \mathrm{mg} / \mathrm{L})$, gypsum (100, 300 and $500 \mathrm{mg} / \mathrm{L})$ and benzocaine (10, 20 and $30 \mathrm{mg} / \mathrm{L})$. Fish were transported in closed systems (plastic bag) at different densities and time periods of up to $24 \mathrm{~h}$. Fish survival (FS) and water quality parameters were monitored immediately after transportation. The remaining fish were kept in floating cages in order to evaluate mortality which occurred up to $96 \mathrm{~h}$ after transportation (S96). The best fish density, additives dosages and time period of the transportation was estimated with a general linear model. The effect of the condition factor on FS and S96 was also evaluated. As expected, FS and S96 were significantly related to time and density. FS but not S96, were also were significantly related to treatment. FS with gypsum treatment was not different from controls and FS with table salt and benzocaine treatments were significantly reduced. The condition factor was not related to either FS or S96. FS was inversely correlated with carbon dioxide concentration. It was concluded that the additives did not improve fish transportation survival. Linear models were developed to predict the best transportation densities as a function of time.
\end{abstract}

Keywords: aquaculture, stress, handling, salt and anesthetic.

\section{RESUMO}

\section{Transporte de juvenis de tambaqui (Colossoma macropomum) em sistema fechado}

O objetivo deste estudo foi investigar o efeito da densidade, duração e do uso de aditivos na água durante o transporte de juvenis de tambaqui (Colossoma macropomum) e usar estes resultados para estabelecer um protocolo seguro de transporte para esta espécie. Os produtos testados e suas doses foram: sal de mesa (1000, 2000 e $3000 \mathrm{mg} / \mathrm{L})$, gesso (100, 300 e $500 \mathrm{mg} / \mathrm{L})$ e benzocaína (10, 20 e $30 \mathrm{mg} / \mathrm{L})$. Os peixes foram transportados em sistema fechado (saco plástico) em diferentes densidades e por diferentes tempos por até $24 \mathrm{~h}$ de transporte. A sobrevivência e os parâmetros de qualidade da água foram monitorados imediatamente após o transporte. Os peixes que sobreviveram ao transporte foram colocados em tanques-rede para avaliar a mortalidade após $96 \mathrm{~h}$. A melhor densidade, tempo de transporte e aditivo foram estimados por modelo linear geral. O efeito do fator de condição na sobrevivência após o transporte e na sobrevivência de $96 \mathrm{~h}$ também foi avaliado. Como esperado, a sobrevivência após o transporte e a sobrevivência de $96 \mathrm{~h}$ foram significativamente correlacionados com o tempo e a densidade. A sobrevivência após o transporte, mas não a sobrevivência de 96 h, também tem correlação com os aditivos testados. A sobrevivência após o transporte é significativamente igual para o tratamento controle e para os tratamentos que receberam gesso 
e significativamente menor para os tratamentos que receberam sal e benzocaína. $\mathrm{O}$ fator de condição não tem correlação com a sobrevivência após o transporte e a sobrevivência de 96 h. É conclusivo que os aditivos testados não melhoram a sobrevivência de juvenis de tambaqui após o transporte. Modelos lineares foram desenvolvidos para predizer a melhor densidade de transporte em função do tempo.

Palavras-chave: aqüicultura, estresse, manuseio, sal e anestésico.

\section{INTRODUCTION}

Tambaqui, Colossoma macropomum, is one of the most popular reared species in the North of Latin America (Araujo-Lima \& Goulding, 1997; Val et al., 2000; Sevilla \& Günther, 2000). This fish easily accepts artificial food, has good productivity and a reliable supply of juveniles.

Commercially produced tambaqui are raised in hatcheries and transported to growout farms or to varzea lakes for stocking programs. In northern Brazil, the juvenile distribution size ranges from 3 to $5 \mathrm{~cm}$, and the main transportation method used is the closed system (Gomes et al., 2002).

Juvenile mortality during and after transportation is high and is a restriction to the productivity of Amazonian fish farms (Andrade \& Randall, 1999; Gomes et al., 2002). Mortality can be related to inadequate transportation, handling or management in the hatcheries.

According to Berka (1986), transportation success depends on many factors including the duration of transportation, temperature of the water, water quality, size and density of the fish, physical condition of the fish, and duration of the depuration period before fish transportation. Juvenile survival is also directly related to dissolved oxygen availability in the water (Wedemeyer, 1996) and elevated carbon dioxide and ammonia levels can also cause fish mortality during transportation, since they accumulate in the water and may reach toxic concentrations (Ross \& Ross, 1999).

The use of salts and anesthetics during juvenile fish transportation is widely used to reduce stress (Guest \& Prentice, 1982; Ross \& Ross, 1999). Among the recommended products are sodium chloride (salt), gypsum and benzocaine, all of which are relatively cheap and easy to use. The salt and gypsum reduce the osmotic gradient between fish and the water (Wedemeyer, 1997), helping the fish to maintain their homeostasis. Benzocaine is considered an efficient and safe anesthetic for juvenile tambaqui (Gomes et al., 2001), but it has not been tested as a transportation additive for this species.
Fish mortality during transportation increases the rearing costs. However, little has been done to reduce this loss. The ideal fish densities of tambaqui in relation to the duration of transportation period, the adequate use of the water-transport additives and the quality of fish have been established at $15 \mathrm{~cm}(50 \mathrm{~g})$ (Gomes et al., 2003a) and $25 \mathrm{~cm}$ (850 g) (Gomes et al., 2003b) fish. The results show that the effect of fish density on transport mortality is size-dependent, therefore it is necessary to investigate these variables for fish that are $3-5 \mathrm{~cm}$ and $1-3 \mathrm{~g}$, which represent around $80 \%$ of the transported tambaqui (Gomes et al., 2002). This is basic information needed to develop transportation protocols for any species.

The objective of the current study is to investigate the effect of density, in the presence or absence of different levels of salt $(\mathrm{NaCl})$, gypsum and benzocaine for up to $24 \mathrm{~h}$, during transportation of juveniles $(3-5 \mathrm{~cm})$ tambaqui. In particular, survival at the end of transportation and delayed mortality up to $96 \mathrm{~h}$ following transport.

\section{MATERIAL AND METHODS}

Tambaqui juveniles [total length $4.09 \pm$ $0.05 \mathrm{~cm}$ and weight $1.19 \pm 0.06 \mathrm{~g}$ (mean $\pm \mathrm{SE}$ )] were acquired from two commercial fish hatcheries in the State of Amazonas, Brazil (Balbina in Presidente Figueiredo and Santo Antônio farm in Rio Preto da Eva). Both hatcheries have similar management protocols for tambaqui broodstock and juvenile production, resulting in equal fish quality (Gomes et al., 2002).

Fish were obtained by induced spawning and raised in a larviculture system for 30-60 days. After this period, juveniles were transferred from the ponds to depuration tanks (1000-3000 L), where they were kept for 12-18 h. After depuration, fish were packed in $30-\mathrm{L}$ plastic bags, with $10 \mathrm{~L}$ of water and filled with pure oxygen. The bags were then closed with rubber bands and placed individually in styrofoam boxes. Transportation was conducted on paved roads. After transportation, the fish survival 
(FS) was quantified, and the remaining fish from each bag were held in separate $1.5 \mathrm{~m}^{3}$ floating cages to evaluate survival after $96 \mathrm{~h}$ (S96). The floating cages were placed in the Catalão Lake, located in the confluence of the Negro and Solimões rivers, Amazon, Brazil.

Juvenile fish were transported at different load densities (15 to $180 \mathrm{fish} / \mathrm{L}$ ) and time periods ( 3 to $24 \mathrm{~h}$ ). The measured unit of fish/L is the main one used in commercial farms that trade juvenile fish in Brazil, therefore it was applied in this study. Three water-transport additives were tested at three different dosages (Table 1), products and dosages were chosen based on their use of different juvenile fish found in the literature (Berka, 1986; Ross \& Ross, 1999). Salt and gypsum were diluted directly in the transportation water, whereas benzocaine was added as an acetone solution $(100 \mathrm{~g} / \mathrm{L})$. Each $\mathrm{mL}$ of acetone solution contained $100 \mathrm{mg}$ of benzocaine. One or two bags of each additive treatment, plus two bags of control treatment (without additives) were transported together in eight independent trips.

Water quality parameters $[\mathrm{pH}$, dissolved oxygen (DO), temperature, ammonia and carbon dioxide $\left(\mathrm{CO}_{2}\right)$ ] were evaluated before transportation and immediately after opening the bags at the end of the transportation. The DO and temperature were measured with YSI 55 probe (Yellow Springs Instruments, Yellow Springs, Ohio, USA); $\mathrm{pH}$ with a digital $\mathrm{pH}$ meter (Digimed model DMPH-2, São Paulo, SP, Brazil); $\mathrm{CO}_{2}$ using titration in accordance with APHA (1992) and, total ammonia according to Verdow et al. (1978). The percentage of un-ionized ammonia was estimated from published tables (Boyd, 1982). Water quality in the bags before transportation were: DO $4.28 \pm 0.5 \mathrm{mg} / \mathrm{L}$, temperature $27.9 \pm 0.5{ }^{\circ} \mathrm{C}, \mathrm{pH} 5.2 \pm 0.08, \mathrm{CO}_{2}$ $8.7 \pm 0.2 \mathrm{mg} / \mathrm{L}$, and un-ionized ammonia $\left(\mathrm{NH}_{3}\right)$ which was undetectable.
The FS and the S96 were logit-transformed, and the effect of time, density and treatments (categorical) were tested with an analysis of covariance (ANCOVA). The adjusted mean FS for each treatment was compared to the control with Dunnett's test $(\mathrm{p}<0.05)$. The same analytical model was applied to the S96. The S96 was corrected by the "natural" mortality rates in ponds of $0.25 \%$ per day. This mortality rate was measured separately, in which 600 juvenile fish were equally distributed in six floating cages $\left(1.5 \mathrm{~m}^{3}\right)$ and their survival was determined after $96 \mathrm{~h}$.

The FS of gypsum treatments and control were pooled, and isolines of survival rate were calculated using multiple linear regressions, with the FS as the dependent variable and transport time and density as independent variables. The model predicted the mean survival rates at any fish density for transportation durations up to $24 \mathrm{~h}$. The control and gypsum groups were combined for the calculations as there was not a significant difference for survival after transportation. The same procedure was applied to S96, but in this case, data of all treatments were used to calculate the multiple linear regression, because there were no significant differences among the treatments.

The relationship between FS residual analyses and water quality parameters (temperature, DO, $\mathrm{pH}, \mathrm{CO}_{2}$ and un-ionized ammonia) was evaluated with the linear regression.

The condition factor (CF) was used to assess juvenile quality (Weters, 2001). When the bags were opened, five fish were randomly selected, measured, weighed, and their condition factor calculated, using the following formula (Weters, 2001): $\mathrm{CF}=(\mathrm{Wg} * 100) / \mathrm{L}^{3}$, where, $\mathrm{Wg}$ is weight $(\mathrm{g})$ and $\mathrm{L}$ is the total length $(\mathrm{cm})$. The mean condition factor of each bag was then estimated, and its effect related to the residuals of the ANCOVA model for FS and S96.

TABLE 1

Products used during the transportation of tambaqui in a closed system and the respective doses.

\begin{tabular}{|l|r|r|r|}
\hline \multicolumn{1}{|c|}{ Product } & \multicolumn{3}{c|}{ Dose (mg/L) } \\
\hline Salt $^{1}(90 \% \mathrm{NaCl})$ & 1000 & 2000 & 3000 \\
\hline Gypsum $^{2}\left(29 \% \mathrm{Ca}^{+2}\right)$ & 100 & 300 & 500 \\
\hline Benzocaine $^{3}($ ethyl-p-aminobenzoate) & 10 & 20 & 30 \\
\hline
\end{tabular}

${ }^{1}$ Sal Lebre ${ }^{\circledR}$, Norsal S. A., RN, BR; ${ }^{2}$ Ingesel Ltda, PE, BR; and ${ }^{3}$ Biomedicinal ${ }^{\circledR}$, AM, BR. 


\section{RESULTS}

TheFS varied significantly with treatments, time and density (Table 2). Treatments with salt and benzocaine reduced the FS average in relation to the control treatment. Treatments with gypsum had a mean FS similar to the control (Fig. 1a). The S96 decreased significantly with time and density, but was not related to the treatment (Table 2 and Fig. 1b), despite showing a similar trend to FS.

Near zero mortality was obtained when transporting fish for $3 \mathrm{~h}$ at densities lower than 100 fish/L. During transportation for 6, 9, 12, 15,18 and $24 \mathrm{~h}$, the maximum densities where no mortality was observed was $90,80,70,60,45$ and 25 fish/L, respectively (Fig. 2). The model

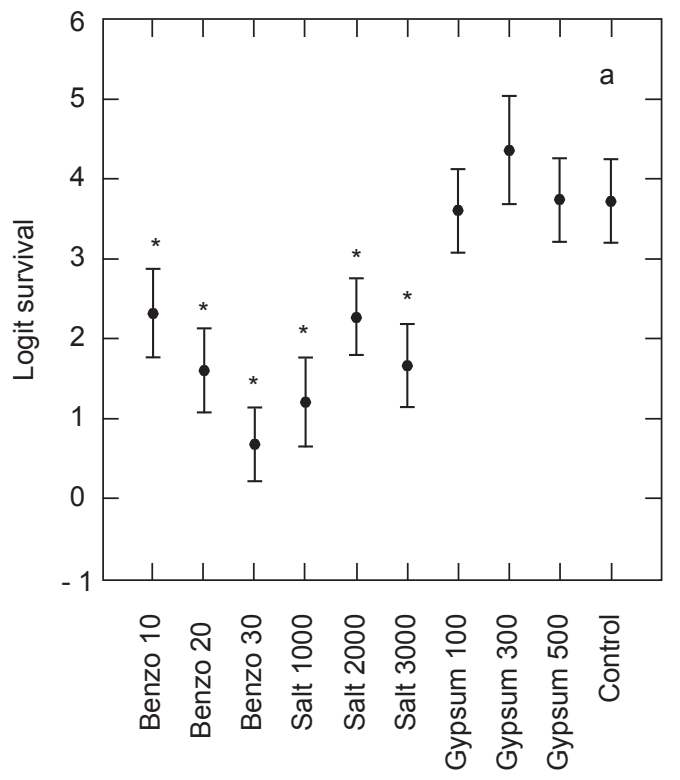

Treatment

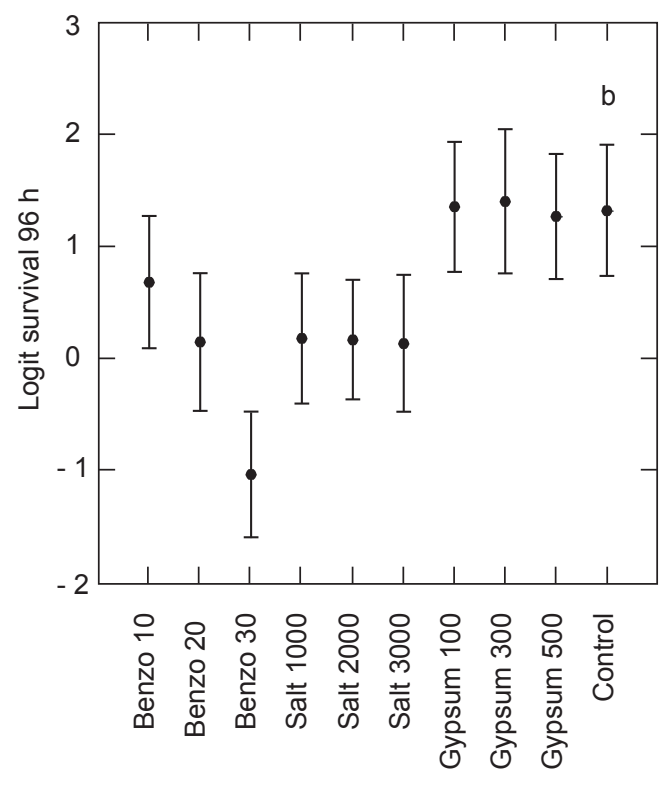

Treatment

Fig. 1 - Survival of juvenile tambaqui after transportation (a) ( $\mathrm{n}=8-10$ for each treatment) and $96 \mathrm{~h}$ after transportation (b) $(\mathrm{n}=10-12$ for each treatment). Data are mean \pm standard error. The numbers after the treatments are the dose in $\mathrm{mg} / \mathrm{L}$. Benzo $=$ benzocaine. $*$ indicates a significant difference from the control, Dunnett's test; $\mathrm{p}<0.05$.

TABLE 2

ANCOVA analyses of juvenile tambaqui survival rates (FS and S96) in closed systems with ten treatments (three salt, gypsum or benzocaine concentrations and control) at different transportation periods $(\leq 24 h)$ and fish densities (15-180 fish/L).

\begin{tabular}{|c|c|c|c|c|c|}
\hline Source of variation & Sum of the squares & df & Mean square & F & P \\
\hline FS; $\mathbf{n}=\mathbf{9 9}$ and $\mathbf{r}^{\mathbf{2}} \mathbf{= 0 . 8 6 3}$ & 133.621 & 9 & 14.847 & 5.450 & $<0.001$ \\
\hline Treatment & 369.537 & 1 & 369.537 & 135.652 & $<0.001$ \\
\hline Time & 447.231 & 1 & 447.231 & 164.172 & $<0.001$ \\
\hline Density & 237.001 & 87 & 2.724 & - & - \\
\hline Error & 62.957 & 9 & 6.995 & 1.872 & 0.065 \\
\hline S96; $\mathbf{n}=\mathbf{1 1 0}$ and $\mathbf{r}^{\mathbf{2}}=\mathbf{0 . 7 0 0}$ \\
\hline Treatment & 200.668 & 1 & 200.668 & 53.698 & $<0.001$ \\
\hline Time & 203.043 & 1 & 203.043 & 54.334 & $<0.001$ \\
\hline Density & 366.221 & 98 & 3.737 & - & - \\
\hline Error &
\end{tabular}




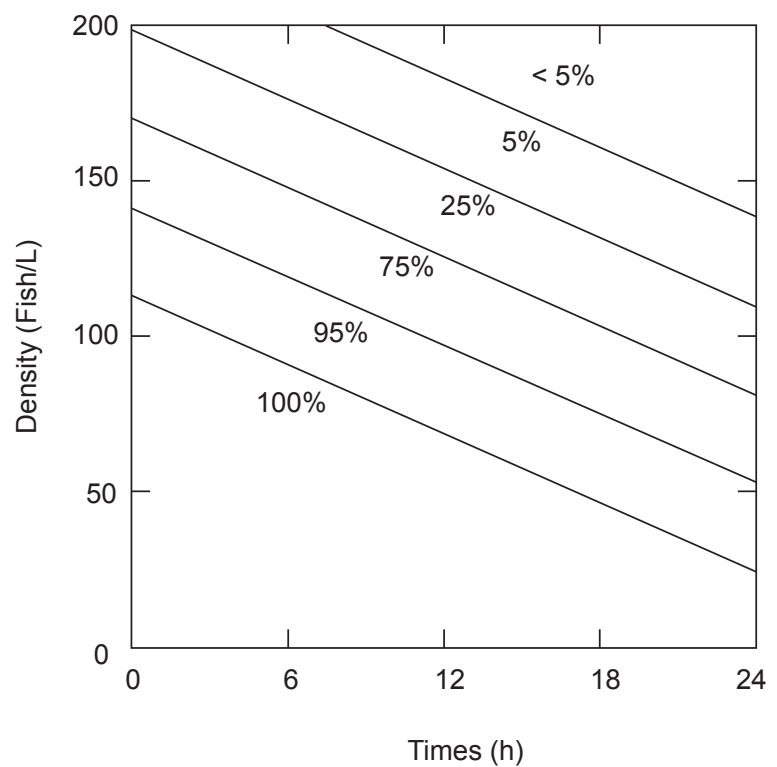

Fig. 2 - Isolines for juvenile tambaqui mean survival (\%) after transportation in the control treatment and using gypsum, in accordance with density and time. Near zero mortality was obtained when fish were transported for $3 \mathrm{~h}$ at densities lower than $100 \mathrm{fish} / \mathrm{L}$. For transportation during 6, 9, 12, 15, 18 and $24 \mathrm{~h}$, the maximum allowed densities, without mortality, were 90 , $80,70,60,45$ and $25 \mathrm{fish} / \mathrm{L}$, respectively. The equation that describes the lines is: logit survival $=12.888-0.258 *$ time $-0.07 *$ density. $\mathrm{n}=36, \mathrm{p}<0.001$ and $\mathrm{r}^{2}=0.771$.

for S96 demonstrated that it was only possible to transport fish without mortality in densities lower than $20 \mathrm{fish} / \mathrm{L}$ for durations less than $3 \mathrm{~h}$ (Fig. 3). For fish transportation of 3, 6, 9 and $12 \mathrm{~h}$, the adequate densities, assuming $5 \%$ mortality, were $70,50,30$ and $20 \mathrm{fish} / \mathrm{L}$, respectively. Mortality increased progressively at longer periods and higher densities.

The condition factor did not influence FS and S96 (Fig. 4). $\mathrm{CO}_{2}$ and FS were inversely correlated $\left(\mathrm{n}=91 ; \mathrm{r}^{2}=0.426 ; \mathrm{p}<0.001\right)$ (Fig. 5). Fifty percent mortality occurred when $\mathrm{CO}_{2}$ concentration was near $200 \mathrm{mg} / \mathrm{L}$. In lower $\mathrm{CO}_{2}$ concentrations ( $<100 \mathrm{mg} / \mathrm{L}$ ) survival was always around $95-98 \%$. DO, temperature, $\mathrm{pH}$ and un-ionized ammonia (Fig. 6) did not affect FS at the range value experimented.

\section{DISCUSSION}

The present study did not provide any evidence of improvement in fish survival during transportation when using water-transport additives. In fact, benzocaine and table salt had a significant negative effect, increasing mortality, and gypsum did not improve the survival over control.
The response of fish to water-transport additives seems to depend on the species and exposure time. Benzocaine is an efficient and safe way to anesthetize juvenile tambaqui for short periods of time (Gomes et al., 2001). Tilapia (Oreochromis niloticus) is safely transported when anesthetized with benzocaine at the same ranges used in the present study (Ferreira et al., 1984). Our results showed that benzocaine during juvenile transportation was not beneficial, since FS was significantly lower than the control group.

It is common knowledge that fish handling during transportation reduces the fish mucus layer, increasing the loss of ions from fish plasma into the water, and the addition of salt reduces the difference in concentration between transport water and fish plasma, reducing the loss of ions (Wurts, 1995). Wurts (1995) also suggested that a concentration of up to $8 \mathrm{~g} \mathrm{NaCl} / \mathrm{L}$ could be used to improve the transportation of fish. Salt reduced the transportation mortality of several species of clupeids (Guest \& Prentice, 1982), striped bass (Morone saxatilis) (Grizzle et al., 1992) and dourado (Salminus maxilosus) (Kubitza, 1998). However, Gomes et al. (1999) concluded that salt 


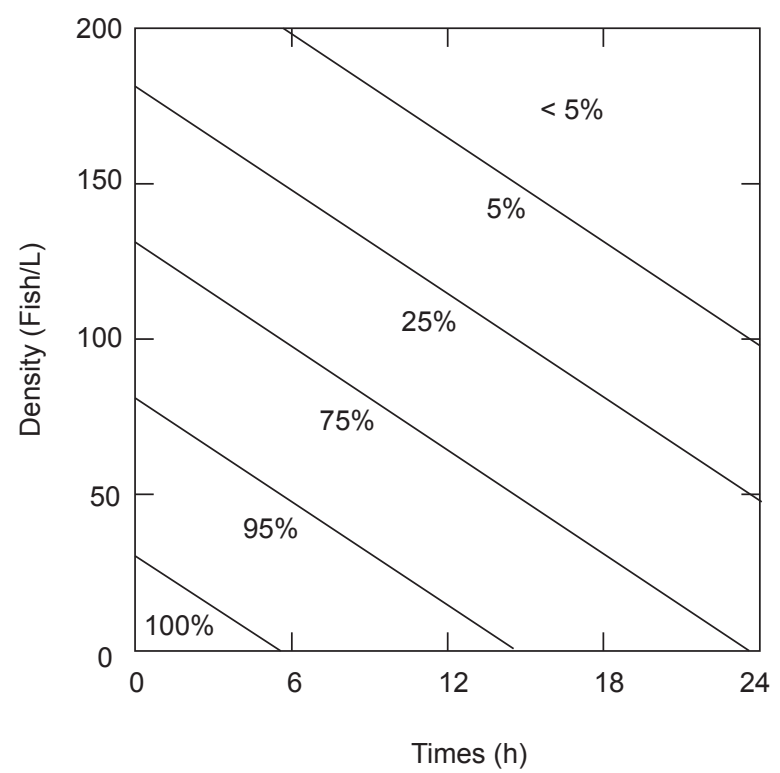

Fig. 3 - Isolines for juvenile tambaqui mean survival (\%) $96 \mathrm{~h}$ after transportation for all tested treatments, in accordance with density and time. It was only possible to transport fish without mortality in densities lower than 20 fish/L and for less than $3 \mathrm{~h}$. For fish transportation of 3, 6, 9 and $12 \mathrm{~h}$, the adequate densities, assuming 5\% mortality, were 70, 50, 30 and $20 \mathrm{fish} / \mathrm{L}$, respectively. The equation that describes the lines is: logit survival $=6.269-0.222 *$ time $-0.04 *$ density. $\mathrm{n}=110, \mathrm{p}$ $<0.001$ and $\mathrm{r}^{2}=0.401$.
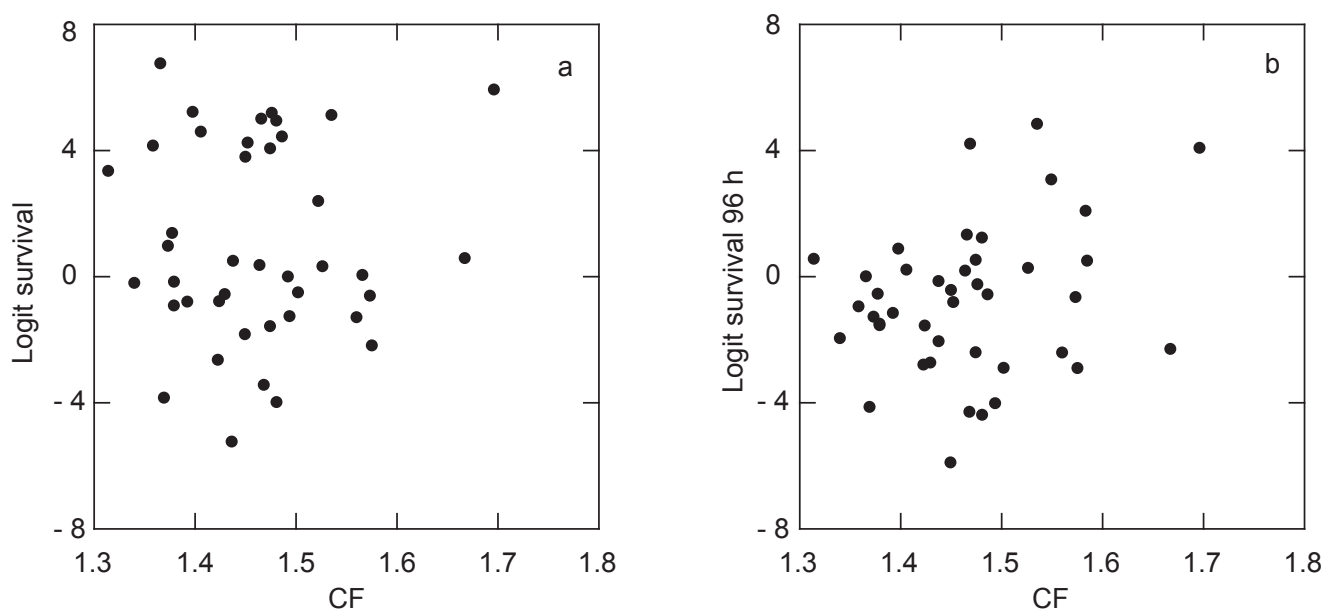

Fig. 4 - Relation between condition factor $(\mathrm{CF})$ and tambaqui juvenile survival after transportation (a) $(\mathrm{n}=41)$ and $96 \mathrm{~h}$ after transportation (b) $(\mathrm{n}=41)$.

increased the mortality during transportation of juvenile silver catfish (Rhamdia quelen) consistent with the findings of the present study. According to Gomes et al. (1999) the main cause for silver catfish mortality was osmoregulation dysfunction due to the addition of salt. Although osmoregulatory parameters were not measured in the present work, the most probable cause for the observed tambaqui mortality was osmoregualtory dysfunction within the fish.

The mean S96 for water-transport additive treatments was not significantly different from 


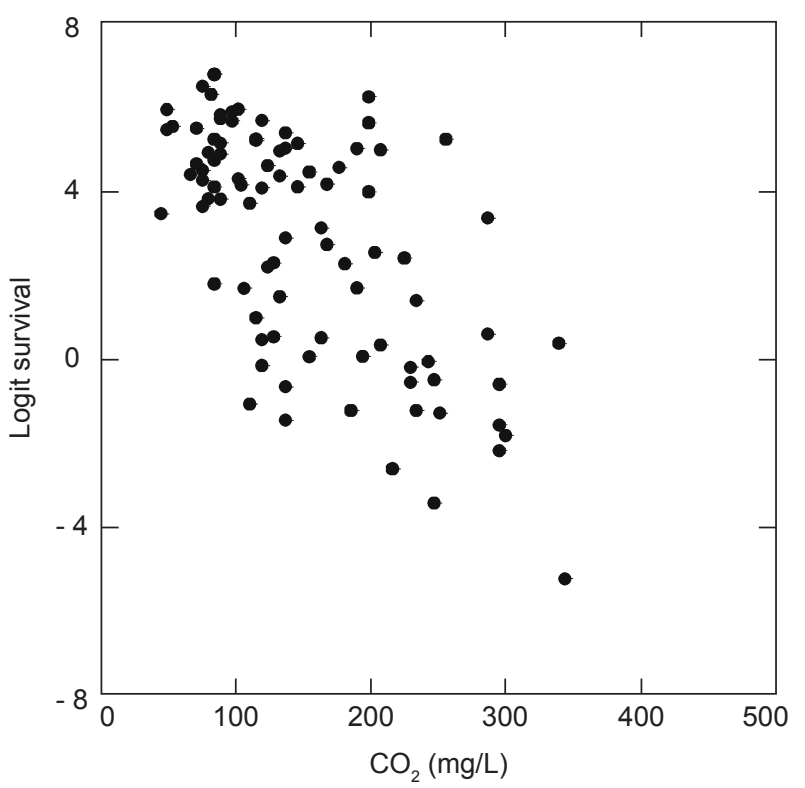

Fig. 5 - Relation between carbon dioxide and tambaqui juvenile survival after transportation in a closed system at different times and densities. The equation that describes the relation is: Logit survival $=6.572-0.025 *$ carbon dioxide. $\mathrm{n}=91$, $\mathrm{p}<0.001$ and $\mathrm{r}^{2}=0.426$.

the control treatment, however the trends were consistent with FS treatments. This is probably due to the high variability between results.

Determination coefficients generated by the models (0.401-0.863) are not high, since all transportation procedures were conducted in a real situation with the influence of several variables, which are common during fish transportation and very difficult to control. Models carried out in real situations are prone to having low coefficients of determination. High coefficients of determination are normally obtained when all or almost all variables are controlled. The results of the generated models have been confirmed from twenty four transportations associated to a tambaqui-stocking program in "varzea" lakes and resulted in a reduction in juvenile mortality during transportation after local hatcheries adopted these models. Therefore, even with low coefficients of determination, the models can be applied as a general guideline in tambaqui transportation.

Juvenile quality is one of the possible variables that could affect survival after transportation (Berka, 1986; Carmichael et al., 2001). In this study, we used the $\mathrm{CF}$ as an index of fish quality, since undernourished fish batches were frequent. The $\mathrm{CF}$ assumed that well-fed fish should be less sensitive to the stress caused by transportation than "skinny" fish (Weters, 2001). Slight fish were easily visible in some of the bags, indicating the variability of this parameter. However, the condition factor did not affect the FS and S96 of tambaqui at the obtained range of variation.

Two possible explanations could explain this result: the index of fish quality was inadequate, or fish quality had a relatively small effect on the survival. Other quality indexes have been used for fish and shrimps, such as: exposure to potentially toxic products (ammonia or formalin) (Samocha et al., 1998; Cavalli et al., 2000) or a stress test, such as withdrawing the animals from the water for a determined period of time (Sakakura et al., 1998). Perhaps, they could be a more efficient predictor of quality for juvenile fish and held to improve the requirements before transportation.

With the exception of $\mathrm{CO}_{2}$, water quality constituents did not have any relation with the fish surviving. Water temperature for fish transportation in the Amazon reached higher values $\left(26-30{ }^{\circ} \mathrm{C}\right)$ than the recommended maximum temperature of $28{ }^{\circ} \mathrm{C}$ for tropical fish transportation by Kubitza (1998), but it did not reduce fish survival. $\mathrm{CO}_{2}$ 

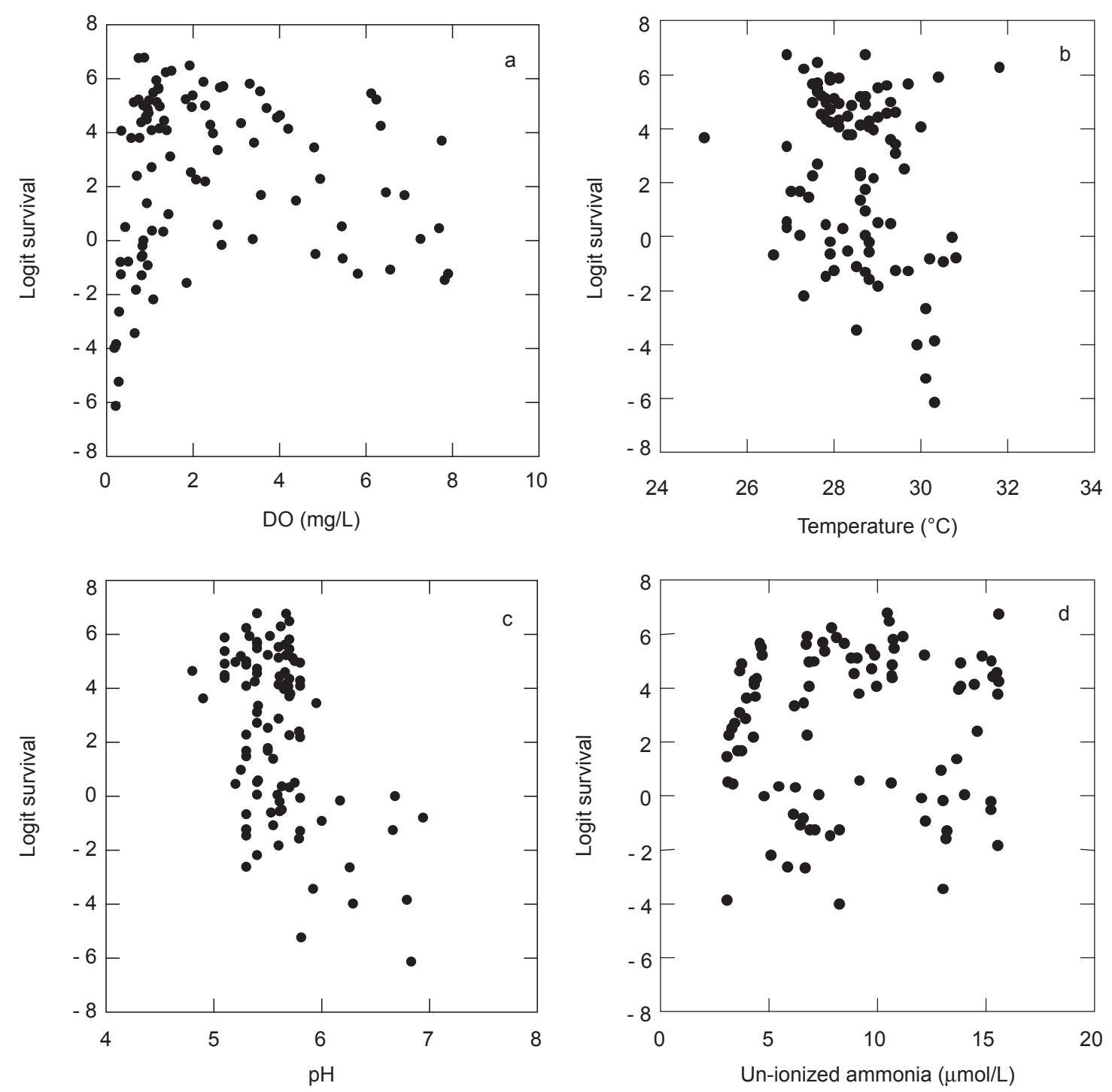

Fig. 6 - Relation between DO (a), temperature (b), pH (c), and un-ionized ammonia (d), and tambaqui juvenile survival after transportation in a closed system at different times and densities $(n=91-99$ for each variable $)$.

and fish survival were inversely correlated. According to Berka (1986), critical values for carbon dioxide during transportation in closed systems depend on the species, but vary between $40 \mathrm{mg} / \mathrm{L}$ for temperate fish species, and up to $140 \mathrm{mg} / \mathrm{L}$ for tropical fish. In this study, fish survival was relatively low when carbon dioxide concentrations were higher than $100 \mathrm{mg} / \mathrm{L}$, and half of the fish died at concentrations of $200 \mathrm{mg} / \mathrm{L}$. This suggests that the critical concentration for juvenile tambaqui is lower than $140 \mathrm{mg} / \mathrm{L}$.

According to Boyd (1982), an increase in $\mathrm{CO}_{2}$ concentration caused a decrease in the $\mathrm{pH}$, which was not observed in this work. Results obtained by Gomes et al. (2003a) and Gomes et al. (2003b) during tambaqui transportation confirmed that this relation does not occur in the transported water from the Amazon, where the $\mathrm{pH}$ remained relatively stable even with the increase in the $\mathrm{CO}_{2}$ 
concentrations. This was somewhat unexpected because hatchery water used in this study is low in ions and has a low buffering capacity (Gomes et al., 2003a). This pH buffering occurs mainly from the combination of the available $\mathrm{H}^{+}$from the respiration process with the $\mathrm{NH}_{3}$ available from the excretion process to produce the $\mathrm{NH}_{4}^{+}$. This process had already been described by Golombieski et al. (2003) during silver catfish (Rhamdia quelen) transportation.

The water $\mathrm{pH}$ in this study (5-7) is similar to the one found in the natural occurrence sites of the species (Wood et al., 1998) as well as in aquaculture ponds. Therefore, this variable was probably not responsible for the physiological or metabolic disturbance in juvenile tambaqui, this is demonstrated by the absence of relationship between $\mathrm{pH}$ and FS.

Due to the characteristic acidity of the water used in the present study, the ammonia toxicity fraction was only between $0.08-0.8 \%$ of total ammonia. As a result, ammonia toxicity was extremely low. According to Ismiño-Orbe (1997), tambaqui is an extremely resistant species to the toxic effect of $\mathrm{NH}_{3}$. The concentrations attained during the study were not harmful to juvenile tambaqui and were lower than the lethal concentration $(27.06 \mu \mathrm{mol} / \mathrm{L})$ for this species (Ismiño-Orbe, 1997), as well as other teleosts, like the channel catfish Ictalurus punctatus (14.12 $\mu \mathrm{mol} / \mathrm{L})$ (Tomasso, 1994) and the turbot Scophthalmus maximus $(23.53 \mu \mathrm{mol} / \mathrm{L})($ Grottum et al., 1997). Ammonia in its ionized state $\left(\mathrm{NH}_{4}^{+}\right)$is less toxic to the fish, however high concentrations can be lethal (Boyd, 1982). Since there was no relationship between fish mortality and ammonia concentration, this variable is not considered to be limiting for juvenile tambaqui transportation when fish are submitted to a starvation period prior to transportation. The stomach depuration process is fundamental in obtaining these results. According to Ross \& Ross (1999) transported fish without a stomach depuration have an intense excretion process, being more susceptible to ammonia toxicity.

The water:oxygen ratio used in this study (1:2) was less than the one recommended by Berka (1986) (1:5) however, this is the standard ratio for the styrofoam transportation boxes used by the fish exporters and in the present study. The use of this method is efficient in the Amazon, since Styrofoam boxes isolate and protect the transportation bags from the sun and heat. As the experimented variation of dissolved oxygen did not have any relation with fish survival, the 1:2 ratio appears to be adequate. The results showed that most fish mortality occurred at DO concentrations lower than $2 \mathrm{mg} / \mathrm{L}$.

The established densities in this study for a $100 \%$ survival after transportation are similar to those recommended to transport juvenile cyprinids (Berka, 1986), but higher than the values reported by Kubitza (1998) for tambaqui at the same water: oxygen ratio. Kubitza (1998) recommended a relation of 1:5 between water and oxygen; in this experiment the ration was of 1:2. However, it would be more conservative to consider the use of densities that achieved high survival after $96 \mathrm{~h}$ after transportation. When using fish survival after $96 \mathrm{~h}$ of transportation as a parameter, the producer has a reliable estimate of transportation mortality.

In conclusion, it was evident that the use of the tested additives is not advisable. The present results established guidelines for safe transportation of juvenile tambaqui. The diagrams enable users to predict the mean losses and plan for adequate densities for transportation as a function of trip duration for up to $24 \mathrm{~h}$.

Acknowledgments - This research was partially supported by "Project Tambaqui" PPD grant \# 1139/99 (contribution \# 8). The authors would like to thank Dr. Colin Brauner from the University of British Columbia for his valuable comments and suggestions. RR is a researcher fellowship recipient from $\mathrm{CNPq} /$ Brazil.

\section{REFERENCES}

ANDRADE, S. M. S. \& RANDALL, E. F., 1999, Avaliação das condições de manejo e doenças nos cultivos de peixe no estado do Amazonas, pp. 17-20. In: T. Cabrera (ed.), Memoria Acuicultura Venezuela 99', Puerto La Cruz.

APHA (American Public Health Association, American Water Works Association, Water Environment Federation), 1992, Standard methods for the examination of water and wastewater, $18^{\text {th }}$ edition. American Public Health Association, New York, 1220p.

ARAUJO-LIMA, C. \& GOULDING, M., 1997, So fruitful fish: ecology, conservation, and aquaculture of the Amazon's tambaqui. Columbia University Press, New York, 157p.

BERKA, R., 1986, The transport of live fish: a review. EIFAC Technical Papers 48, FAO, Rome, 57p.

BOYD, C. E., 1982, Water quality management for pond fish culture. Elsevier, Amsterdam, 317p. 
CARMICHEL, G. J., TOMASSO, J. R. \& SCHWEDLER, T. E., 2001, Fish transportation, pp. 641-660. In: G. A. Wedemeyer (ed.), Fish Hatchery Management, second edition, American Fisheries Society, Bethesda.

CAVALli, R. O., BERGHE, E. V., LAVENS, P., THUY, N. T. T., WILLE, M. \& SORGELOOS, P., 2000, Ammonia toxicity as a criterion for the evaluation of larval quality in the prawn Macrobrachium rosenbergii. Comp. Biochem. Physiol., 125C: 333-343.

FERREIRA, J. T., K, H. J. \& SMIT, G. L., 1984, The use of benzocaine-hydrochloride as an aid in the transport of fish. Aquaculture, 42: 69-174.

GOLOMBIESKI, J. I., SILVA, L. V. F., BALDISSEROTTO, B. \& SILVA, J. H. S., 2003, Transport of silver catfish (Rhamdia quelem) fingerlings at different times, load densities, and temperatures. Aquaculture, 216: 95-102.

GOMES, L. C., GOLOMBIESKI, J. I., CHIPPARI-GOMES, A. R. \& Baldisserotto, B., 1999, Effect of salt in the water of transport on survival and $\mathrm{Na}^{+}$and $\mathrm{K}^{+}$body levels in fingerlings of silver catfish Rhamdia quelen (Pimelodidae). J. Appl. Aquacult., 9: 1-9.

GOMES, L. C., CHIPPARI-GOMES, A. R., LOPES, N. P., ROUBACH, R. \& ARAUJO-LIMA, C. A. R. M., 2001, Efficacy of benzocaine as an anesthetic in juvenile tambaqui Colossoma macropomum. J. World Aquacult. Soc., 32: 426-431.

GOMES, L. C., ROUBACH, R. \& ARAUJO-LIMA, C. A. R. M., 2002, Transportation of tambaqui juveniles (Colossoma macropomum) in Amazon: main problems. World Aquacult., 33: 51-53.

GOMES, L. C., ARAUJO-LIMA, C. A. R. M., ROUBACH, R., CHIPPARI-GOMES, A. R., LOPES, N. P. \& URBINATI, E. C., 2003a, Effect of fish density during transportation on stress and mortality of juvenile tambaqui Colossoma macropomum. J. World Aquacult. Soc., 34: 76-84.

GOMES, L. C., ARAUJO-LIMA, C. A. R. M., ROUBACH, R. \& URBINATI, E. C., 2003b, Avaliação dos efeitos da adição de sal e da densidade no transporte de tambaqui. Pesq. agropec. bras., 38: 283-290.

GRIZZLE, J. M., MAULDIN, A. C. \& ASHFIELD, C. J., 1992, Effects of sodium and calcium chloride on survival of larval striped bass. J. Aquat. Anim. Health., 4: 281-285.

GUEST, W. C. \& PRENTICE, J. A. 1982. Transportation techniques for blueback herring. Prog. Fish-Cult., 44: 183-185.

GROTTUM, J. A., STAURNES, M. \& SIGHOLT, T., 1997, Effect of oxygenation, aeration and $\mathrm{pH}$ control on water quality and survival of turbot, Scophtalmus maximus (L.), kept at high densities during transport. Aquac. Res., 28: $159-164$.
ISMIÑO-ORBE, R. A., 1997, Excreção e efeito da amônia sobre o crescimento do tambaqui (Colossoma macropomum Cuvier, 1818). Master's thesis. Instituto Nacional de Pesquisas da Amazônia, Manaus, Amazonas, Brazil.

KUBITZA, F., 1998, Técnicas de transporte de peixes vivos. Campo Grande, 44p.

ROSS, L. G. \& ROSS, B., 1999, Anaesthethic and sedative techniques for aquatic animals. Blackwell Science, Oxford, $159 \mathrm{p}$.

SAKAKURA, Y., KOSHIO, S., IIDA, Y., TSUKAMOTO, K., KIDA, T. \& BLOM, J. H., 1998, Dietary vitamin C improves the quality of yellowtail (Seriola quinqueradiata) seedlings. Aquaculture, 161: 427-436.

SAMOCHA, T. M., GUAJARDO, H., LAWRENCE, A. L., CASTILLE, F. L., SPEED, M., MCKEE, D. A. \& PAGE, K. I., 1998, A simple stress test for Penaeus vannamei postlarvae. Aquaculture, 165: 233-242.

SEVILLA, A. \& GÜNTHER, J., 2000, Growth and feeding level in pre-weaning Tambaqui Colossoma macropomum Larvae. J. World Aquacult. Soc., 31: 218-224.

TOMASSO, J. R., 1994, Toxicity of nitrogenous wastes to aquaculture animals. Rev. Fish. Sci., 2: 291-314.

VAL, A. L., ROLIM, P. R. \& RABELO, H., 2000, Situação atual da aqüicultura na região norte, pp. 247-266. In: W. C. Valente, C. R. Poli, J. A. Pereira \& J. R. Borghetti (eds.), Aquiicultura no Brasil: bases para um desenvolvimento sustentável, $\mathrm{CNPq} / \mathrm{MCT}$, Brasília.

VERDOW, H., VANECHTED, C. J. A. \& DEKKERS, E. M. J., 1978, Ammonia determination based on indophenol with sodium salicylate. Water Res., 12: 399-402.

WEDEMEYER, G. A., 1996, Physiology of fish in intensive culture systems. Chapman \& Hall, New York, 232p.

WEDEMEYER, G. A., 1997, Effect of rearing conditions on the health and physiological quality of fish in intensive culture, pp. 35-71. In: G. K. Iwama, A. D. Pickering, J. P. Sumpter \& C. B. Schreck, (eds.), Fish stress and health in aquaculture, Society for Experimental Biology Seminar Series 62, Cambridge University Press, Cambridge.

WETERS, H., 2001, Production, pp. 31-90. In: G. A. Wedemeyer (ed.), Fish Hatchery Management, second edition, American Fisheries Society, Bethesda.

WOOD, C. M., WILSON, R. W., GONZALEZ, R. J., PATRICK, M. L., BERGMAN, H. L., NARAHARA, A. \& VAL, A. L., 1998, Responses of an Amazonian teleost, the tambaqui (Colossoma macropomum), to low $\mathrm{pH}$ in extremely soft water. Physiol. Zool., 71: 658-670.

WURTS, W. A., 1995, Using salt to reduce handling stress in channel catfish. World Aquacult., 26: 80-81. 